\title{
Detection of Estrogen and IL-17A Levels in Serum of Premenopausal and Postmenopausal Women in Kirkuk City Iraq
}

\author{
Najdat Ali Al-Kadhi ${ }^{1}$, Fatima Mustafa Mohammed ${ }^{2}$, Ektifa Abdulhameed ${ }^{3}$ and Chateen I Ali \\ Pambuk $^{2 *}$ \\ ${ }^{1}$ Kirkuk Technical College, Northern Technical University, Iraq \\ ${ }^{2}$ College of Dentistry, Tikrit University, Iraq \\ ${ }^{3}$ College of Education for Women, Tikrit University, Iraq
}

Received: June 14 ${ }^{\text {th }}, 2017$; Accepted: July 21 ${ }^{\text {st }}, 2017$; Published: July $28^{\text {th }}, 2017$

*Corresponding author: Dr. Chateen I. Ali Pambuk, Assistant Professor, College of Dentistry University Of Tikrit, PhD Medical Immunology, Tel: 009647701808805; E-mail: dr.chatin2@yahoo.com

\begin{abstract}
The study aimed to the detection of estrogen \& IL-17A levels in the serum of apparently healthy postmenopausal women. The study carried out on the 190 women, they were divided randomly to two groups: the first group included 90 postmenopausal women $\&$ the second group was included 100 premenopausal women. From each subject $(5 \mathrm{ml})$ of venous blood were drawn in plain tube \& centrifuged by centrifuge for 5 minutes at $3000 \mathrm{rpm}$. The serum was used for evaluation of IL-17A By Enzyme Linked Immunosorbent Assay (ELISA), while the level of estrogen was determined by the minividas. The results of the study were recorded a significant decline $(p<0.01)$ in the concentration of estrogen \& significant decrease $(p<$ 0.05 ) in the level of IL-17A in the serum of postmenopausal women when compared with the premenopausal women. From the results of the study, we concluded a significant decline in the levels of IL-17A, which may be contributed to the significant decrease in the level of estrogen in the Serum of postmenopausal women. In conclusion, the postmenopausal women recorded a significant decline in the serum concentration of IL-17A particularly in the presence of Lower estrogen level.
\end{abstract}

KEYwoRDS: Pre and Postmenopausal; Interleukin-17A; Estrogen

\section{Introduction}

The state of Menopause in women life considered as an important physiological process, characterized by the dramatic cessation of menstruation due to the loss of ovarian follicular activity [1]. The onset of menopause associated with the decline in the levels of estrogen and consequently alteration of lipid fractions in the serum of menopausal women $[2,3]$. Deficiency of some hormones during menopause associated with the lower systemic inflammatory status, which inflammation manifested by the increased serum levels of key proinflammatory cytokines IL1, IL-6 or tumor necrosis factor alpha TNF- ) [4].

The incidence of cardiovascular events increases when there are several circulating inflammatory markers including hs-CRP \& IL-6[5]. Recently, approved that the elevation of serum levels of IL-8 in premenopausal ,perimenopausal, postmenopausal women \& oophorectomized women with sever hot flushes were significantly higher than those in women without hot flushes[6]. In chronic inflammatory disease, a new candidate IL17A produced by T helper 17 (Th17) lymphocytes \& effects on neutrophil recruitment \& granulopoieses [7]. Estrogen deficiency in postmenopausal women recorded significant increase in IL17A level which highlighted to its role in chronic inflammatory events \& increases their susceptibility to the chronic inflammatory disease [8].

Significant decrease of estrogen concentration in menopausal women regarded to the acceleration or aggravation of immune \& inflammatory events which leads for the libration of proinflammatory cytokines such as IL-1, IL-6, TNF- \& IL17 resulting an immune dysfunction $[9,10]$. The relationship between hormonal decline associated with the menopause \& increased serum levels of proinflammatory cytokines is not yet fully understood. So this study aimed to investigate the level of serum estrogen \& IL-17A in healthy women at the premenopausal \& postmenopausal status.

\section{Materials \& Methods}

\section{Study Population}

For detection of estrogen level, the study carried out on 190 healthy premenopausal (mean age 36 years) \& postmenopausal (mean age 36 years) women. The 100 premenopausal women were divided randomly to two subgroups, the first subgroup included 63 women (mean age 30.5 years) \& second subgroup included 37 women (mean age 40 years). While 90 healthy postmenopausal women were divided to two subgroups, the first subgroup included 67 women (mean age 54.5 years) \& second subgroup included 23 women (mean age 63 years).

For detection of serum IL-17A level, the study carried out on 74 women were 40 of them at premenopausal state while 34 of them at the postmenopausal state. Blood samples were collected on fasting for 10-14 hrs. Serum were obtained \& kept at deep freeze $\left(-20 \mathrm{C}^{0}\right)$ till use. 


\section{Detection of Estrogen Concentration}

Total serum estrogen level quantitatively determined according to the Vidas estradiol 11 test by vidas instrument which used Enzyme Linked Fluorescently Assay (ELFA) techniques. (According to the technical specification provided by the manufacturer).

\section{Detection of Interleukin 17A Level}

Serum IL-17A level were detected by Human IL-17 Elisa kit from (Bioassay technology laboratory / USA), applied the method of Enzyme Linked Immunosorbent Assay (ELISA) from (Biotekelx800, USA). (According to the technical specification provided by the manufacturer).

\section{Statistical Analysis}

The data were analyzed by the statistical program by Minitab according to T-test. The data displayed as Mean \pm SD. P- value $\left(p^{`}<0.05\right)$ refers to the statistically significant differences and ( $p$ $<0.01$ ) refers to highly significant differences.

\section{Results}

The results of the study revealed in the Table 1 , that the serum of estrogen concentration recorded a significant decrease $\left(\mathrm{p}^{`}<0.01\right)$ in postmenopausal women $(38.1+11.58) \mathrm{ng} / \mathrm{L}$ when compared with the premenopausal women ( $192.24+$ 41.13 ) ng/L , while there was no significant differences ( $\mathrm{p}>$ 0.05 ) between subgroups ( age groups ), as in premenopausal subgroups existed ( $196 \pm 42.13),(186.81 \pm 35.08) \mathrm{Ng} / \mathrm{l} \&$ in postmenopausal subgroups existed $(46.53 \pm 11.70),(31.20 \pm$ 9.52) ng/l.

Table 1: Concentration of estrogen (ng/l) in serum of premenopausal and Postmenopausal women.

\begin{tabular}{|c|c|c|c|c|}
\hline Subjects & $\begin{array}{l}\text { Total } \\
\text { No. }\end{array}$ & $\begin{array}{l}\text { Study } \\
\text { Groups }\end{array}$ & $\begin{array}{c}\text { Estrogen } \\
\text { Level } \\
\text { (Ng/L ) } \\
\text { Mean } \pm \text { SD }\end{array}$ & Total \\
\hline \multirow{4}{*}{$\begin{array}{c}\text { Premenopausal } \\
\text { Women }\end{array}$} & \multirow{4}{*}{100} & $\begin{array}{c}27-34 \\
\text { years }\end{array}$ & \multirow[t]{2}{*}{$\begin{array}{c}196.27 \pm \\
42.13\end{array}$} & \multirow{4}{*}{$192.24 \pm 41.13$} \\
\hline & & $N=63$ & & \\
\hline & & $\begin{array}{c}35-45 \\
\text { years }\end{array}$ & \multirow[t]{2}{*}{$\begin{array}{c}187.81 \pm \\
35.08\end{array}$} & \\
\hline & & $N=37$ & & \\
\hline \multirow{4}{*}{$\begin{array}{c}\text { Premenopausal } \\
\text { Women }\end{array}$} & \multirow{4}{*}{90} & $\begin{array}{l}51-58 \\
\text { years }\end{array}$ & \multirow{2}{*}{$\begin{array}{c}46.53 \pm \\
11.70\end{array}$} & \multirow{4}{*}{$38.10 \pm 11.58$} \\
\hline & & $N=67$ & & \\
\hline & & $\begin{array}{c}59-67 \\
\text { years }\end{array}$ & \multirow[t]{2}{*}{$\begin{array}{c}31.20 \pm \\
9.52\end{array}$} & \\
\hline & & $N=23$ & & \\
\hline
\end{tabular}

Fig. 1 showed the results of IL-17A level in the serum, which recorded a significant decrease $(\mathrm{p}<0.05)$ in postmenopausal women $(22.16+3.1) \mathrm{ng} / \mathrm{L}$ when compared with the premenopausal women $(30.87+6.15) \mathrm{ng} / \mathrm{L} .{ }^{* *}$ Highly significant $\mathrm{p}<0.01$

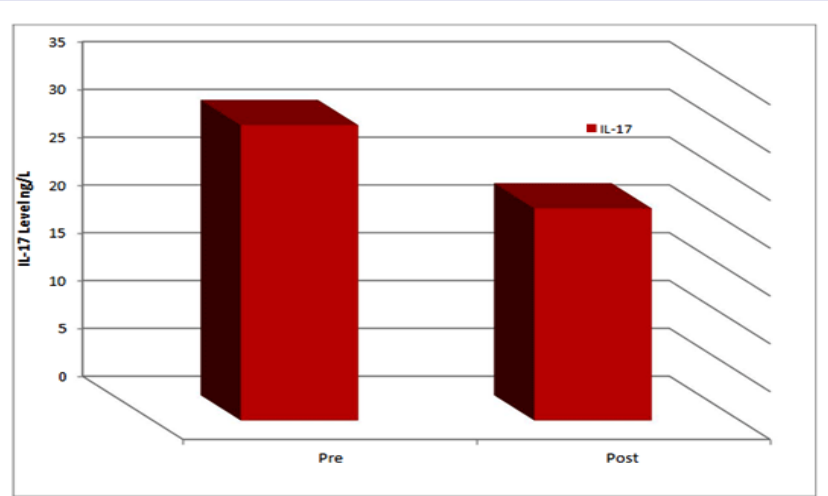

Figure 1: Reveals concentration of IL-17A (ng/l) in serum of premenopausal and postmenopausal women.

\section{Discussion}

The onset of menopause associates with the onset of alterations in the hormonal \& systemic inflammatory status. The process of the inflammation characterized by increased key proinflammatory cytokine levels in the serum. Cytokines are signaling protein molecules with important role in intercellular communication. Their sources from all cells \& tissues, which differentiates them from hormones [11,12].

From the results of the study which revealed a significant decrease $(p<0.01)$ in the levels of estrogen in the serum of postmenopausal women as shown in Table 1 \& Fig.1, that this finding were compatible with many studies. Kilm \& Chandala 213 found that the level of estrogen were low in postmenopausal women [13]. The level of estrogen decrement in postmenopausal women was considered normal state [14]. Cessation of the menstruation is a common event in menopause which results from cessation of the activity of the ovarian follicles, due to hormonal deficiency, which is a contributory factor for the increased incidence of inflammatory disease [15].

Also, the disturbances in the level of lipid \& lipoprotein fractions in the serum, in addition to the negative alterations in the levels of glucose, insulin metabolism, fat distribution, blood coagulation, fibrinolysis \& endothelial defects results from an abrupt decline in the level of estrogen hormone [16]. Moreover, estrogen plays a significant role for heart (protective role) by increases release of nitrous oxide, which is important for stabilizing of endothelial cells \& synergize the antioxidant effects with the changes of fibrinolytic proteins which all of them considered from cardio-protective mechanism which lost with the onset of menopause $[17,18]$. While a significant decline of estrogen level in postmenopausal women have many undesirable changes which influences on the health of women, because there are an association between estrogen decrement in postmenopausal women with fat deposition in the body \& an increase the incidence of many disease, and alteration of HDL, LDL levels, leads to great impact for the development of cardiovascular disease [19-22].

The results of the study also revealed a significant decrease $(p<0.05)$ in the levels of IL-17A for postmenopausal women. This result were incompatible with the results of [7] found the increment of IL-17A level associated highly with the age \& period 
of menopause in postmenopausal women were they suffered from osteoporosis. There are relationship between IL-17A level in serum \& osteoporosis [23]. Also incompatibility may belong to the method of IL-17A detection or to the type of kits, materials \& instrument which used for the detection of IL-17A. On other hand the results of our study were compatible with the results of were found that the levels of serum IL-17A, IL-4 \& IL-10 decrement recorded in surgically induced menopause or natural menopausal women in comparison with the premenopausal women. So the relationship between hormonal decline \& alterations in the level of cytokines not yet fully understood, but some studies demonstrated that the cells of postmenopausal women were less active for the release of cytokines in comparison with the premenopausal women $[12,14]$.

The study concluded a significant decline in the levels of IL-17A which contribute to the significant decrease in the concentration of estrogen hormone in the serum of postmenopausal women.

\section{References}

1. Andrei M, Mihu D, Costin N, Mihu C. Proinflimmatory and antiinflammatory cytokine changes related to menopause. Prezeglad Menopauzalny J. 2014;13 (3) : 162-168; Doi :10.5114/pm.2014.43818

2. Kilim S.R, Chandala S. R. A comparative study of lipid profile and oestradiol in pre\& postmenopausal women. J Clin Diagn Res. 2013; 7 (8):1596-1598; Doi:10.7860/JCDR/2013/6162.3234

3. Bade G, Shah S, Nahar P, Vaidya S. Effect of menopause on lipid profile in relation to body mass index. Chronicles of Young Sci. 2014; 5 (1): 20-24

4. Charles C, Yuskavage J, Carlson O, John M, Tagalicud AS, Maggio M, et al Effect of high dose isoflavones on metabolic \& inflammatory markers in healthy Postmenopausal women. Menopause. 2009;16(2):395400;Doi: 10.1097/gme.0b013e3181857979

5. Ridker PM, Hennekens CH, Buring JE, Rifai N. C-reactive protein and other markers of inflammatory in prediction of CVD in women. N. Engl J Med. 2000;342:836-843; Doi :10.1056/NEJM200003233421202

6. Yasui T, Uremura H, Tomita J, Miyatani Y, Yamada M, Kuwahara A, et al. Association of interleukin-8 with hot flushes in premenopausal, perimemopausal and postmenopausal women and bilateral oophorectomized women. J Clin Endocrinol Metab. 2006;91(12):48054808;Doi:10.1210/jc.2006-1100

7. Molnar I. The role of IL-17A in postmenopausal inflammatory events, Such as in osteoporosis. 4th international Conference \& exhibition on Immunology. OMICS;2015

8. Molner I, Bohaty I, Somogyine-Vari E. IL-17A mediated RANK ligand elevation involved in postmenopausal osteoporosis. Osteoporosis International. 2014;25(2):783-786; Doi:10.1007/s00198-013-25486
9. Teitelbaum SL. Postmenopausal osteoporosis, T cell, and immune dysfunction. Proc Natl Acad Sci.2014;101(48): 16711 - 16712; Doi: 10.1073/pnas.0407335101

10. Tyagi AM, Srivastava K, Mansoori MN, Trivedi R, Chattopadhyay $\mathrm{N}$, Singh D. Estrogen deficiency induces the differentiation of IL17 secreting Th 17 cells: a new candidate in the pathogenesis of osteoporosis of osteoporosis. Plos one.2012;7(9):445-452;Doi: 10.1371/journal.pone.0044552

11. Cannon JG. Inflammatory cytokines in non pathological state. News Physiol Sci. 2000;15:298-303

12. Malutan A.M, Costin N, Ciortea R, Mihu D. Variation of antiinflammatory cytokines in relationship with menopause. Applied Med Informatics.2013;32(2):30-38

13. Kilim R.K, Chandala R.C. A comparative study of conventional risk factors in patients with coronary heart disease. JAMA. 2013; 290(7):898-904

14. Sultan N, Nawaz M, Sultan A, Fayaz M, Baseer A. Effect of menopause on serum HDL- cholesterol level. J. Ayub Med Coll Abbottabad. $2003 ; 15(3) 24-26$

15. Su HI, Freeman EW. Hormone changes associated with the menopausal transition. Minerva Ginecol.2009;61(6):483-489

16. Bales AC. In search of lipid balance in order women. New studies raise questions about what works best. Postgrad Med. 2000;108(7):57-72; Doi :10.3810/pgm.2000.12.1312

17. Igweh JC, Nwagha IU, Karo JM. The effects of menopause on the serum lipid profile of normal females of south east Nigeria. Niger J Physiol Sci. 2005;20(1-2):48-53

18. Taddei S, Virdis A, Ghiadoni L, Mattei P, Sudano I, Bernini G, et al. Menopause is associated with endothelial dysfunction in women. Hypertension. 1996;28(4):576-582

19. Pisani M. Aging \& lung disease. A clinical guides Springer. 2012; P: 157

20. Pollard M. Western Disease: An evolution perspective. Cambridge University press. 2008;P: 92

21. Goroll A., Mulley A. Primary care medicine: Office evaluation \& management of the adult patient. Lippincott Williams \& Wilkins. 2012;P:20-24

22. Davis SR, Lambrinoudalei I, Lumsden M, Mishra GD, Pal L, Rees M, et al. Menopause. Nature review, Disease primers. 2015;1:1-19

23. Korayem HK, Rezk MM, Hassan MM, El-Tawab SS, Elsaid SS. Relation between serum IL-17 level \& risk of osteoporotic fracture in premenopausal rheumatoid arthritis patient: Clinical, radiological, laboratory studies. The Egyptian Rheumatology; Available online J. 2015 